\title{
Budget Participation Capacity Configuration (BPCC), Budgeting Participation Requirement and Product Innovation Performance
}

\author{
Mu-Jung Huang ${ }^{1}$, Kuo-Chih Cheng ${ }^{1}$, Shao-Hsi Chung ${ }^{2, *} \mathbb{C}$, Huo-Ming Wang ${ }^{3}$ and Kuo-Hua Wang ${ }^{3}$ \\ 1 Department of Accounting, National Changhua University of Education, Changhua 500, Taiwan; \\ mjhuang8601@gmail.com (M.-J.H.); h12343562@ms46.hinet.net (K.-C.C.) \\ 2 Department of Business Administration, Meiho University, Pingtung 912, Taiwan \\ 3 Department of Finance, National Changhua University of Education, Changhua 500, Taiwan; \\ bikewang@gmail.com (H.-M.W.); wanglee1968@gmail.com (K.-H.W.) \\ * Correspondence: x00003166@meiho.edu.tw
}

\section{check for} updates

Citation: Huang, M.-J.; Cheng, K.-C.; Chung, S.-H.; Wang, H.-M.; Wang, K.-H. Budget Participation Capacity Configuration (BPCC), Budgeting Participation Requirement and Product Innovation Performance. Sustainability 2021, 13, 5614 . https://doi.org/10.3390/su13105614

Academic Editors: Tsu-Ming Yeh, Fan-Yun Pai, Hsin-Hung Wu and Yuh-Wen Chen

Received: 16 April 2021

Accepted: 11 May 2021

Published: 18 May 2021

Publisher's Note: MDPI stays neutral with regard to jurisdictional claims in published maps and institutional affiliations.

Copyright: (c) 2021 by the authors. Licensee MDPI, Basel, Switzerland. This article is an open access article distributed under the terms and conditions of the Creative Commons Attribution (CC BY) license (https:/ / creativecommons.org/licenses/by/ $4.0 /)$.

\begin{abstract}
As the relationship between the execution of budget participation and innovation performance is still full of controversy, and the innovation capability formed by the important control elements of the organization is the key to bring about product innovation performance, this study aims to explore the impact of the formation of product innovation capabilities on product innovation performance under the demand for budget participation. This study proposes the concept of budget participation capacity configuration (BPCC), which is the integration of procedural justice, self-efficacy, and trust in superiors. This study adopted a questionnaire survey to collect sample data from production managers of the electronics-related companies listed on the Taiwan Stock Exchange and employed structural equation modeling to verify measurement model fit and research hypotheses. The study results present that budgeting participation requirement does not directly affect product innovation performance and confirms that the three organizational control elements together constitute BPCC, which plays a fully intermediary role between budget participation requirement and product innovation performance. The contribution of this research for academic theory is to put forward an explanation of the budget participation-innovation performance dispute, and propose an integrated viewpoint for organizational control elements instead of fragmental studies in the past. For practice, this research provides new evidence for budget participation requirements and sources of innovation capabilities.
\end{abstract}

Keywords: BPCC; procedural justice; self-efficacy; trust; product innovation performance

\section{Introduction}

Taiwan is experiencing COVID-19 and the Sino-US trade war. Uncharacteristically, Taiwan's electronics-related industry presents the fact that Taiwan's output value in the fields of foundry, packaging, and testing is the highest in the world, and its chip design and DRAM manufacturing ranks second in the world. The scale of these industries has at least doubled in the past five years. Especially, in the last year, the output value of the LCD panel factory exceeded TWD 1 trillion and surpassed its rival South Korea to become the world's first in output value. Therefore, the electronics-related industry in Taiwan occupies a pivotal role in the international arena. In the management literature, Taiwan's electronics-related industry innovation has an important relationship with the industry managers' budget participation [1-4].

Taiwan's high-tech industry is facing global competition and the shortening of product life cycles. In order to maintain the competitive advantages and continuous sales growth of electronic components and products, companies should continue to innovate their manufacturing processes and products. Therefore, how to respond to the improvement of product innovation performance has become a topic that the academic and practical circles attach great importance to [5-8]. In the past, most studies believed that companies should 
have the ability to innovate products in order to respond to the needs of innovation $[9,10]$. This study suggests that the so-called product innovation capability is formed by the alignment of important factors within the organization. This viewpoint is the same with previous studies that the key factors of organizational resources should be configured to promote innovation [11-14].

Budget is a necessary resource for product innovation and participating in budget allocation is a necessary way for department managers to obtain appropriate budgets [2,4]. Prior studies have extensively discussed the relationship between budget and product innovation $[15,16]$, but there is a lack of research on budget participation requirement and product innovation performance. In the research on the effectiveness of budget participation, it is considered that procedural justice, self-efficacy, and trust in superiors are significant organizational control elements, which have the ability to improve organizational performance $[1,17-20]$. Thus, to explore whether these organizational elements can be integrated to form product innovation capabilities, namely budget participation capacity configuration (BPCC) in this study. It is one of the motivations of this study. In addition, past studies on budget participation and organizational effectiveness have not yet consistently determined the relationship between the two [21-25]. Therefore, another motivation of this study attempts to include BPCC and consider its impact on the relationship between budget participation requirement and product innovation performance. Based on the motivations of this study and theories of Venkatraman's [26] "fit as covariation" and "fit as mediation", the study intends to explore the following two issues:

(1) Can the organizational factors such as procedural justice, self-efficacy and trust in superiors that make up the "Budget Participation Capacity Configuration (BPCC)" be integrated to form a product innovation capability?

(2) Can the requirement of budgeting participation lead to the generation of BPCC, and then BPCC improves the performance of product innovation?

The results of this study contribute to develop relevant theories of product innovation capabilities and provide explanations for the controversial on budget participationorganizational effectiveness relationship. In practice, the results are an important reference for companies considering the internal elements of their organization to respond to the need of product innovation capacity. The remainder of this paper is organized as follows: Section 2 reviews related research literature and derives research hypotheses. Section 3 describes the research method, data, and measurements. Section 4 presents the research results. Section 5 discusses the results. Finally, Section 6 concludes the paper, along with management implications, limitations, and future research recommendations.

\section{Literature Review and Hypothesis Development}

Since the impact of environments on a high-tech firm's decision makings cannot be easily predicted, the operational planning and control of the firm become more difficult. For managing uncertain environments of technology change, the firm should properly adjust its significant factors of organization [27-30]. This study suggests that there should be an internal aligning relationship among organizational factors. Such integration is the concept of BPCC, which including procedural justice, self-efficacy, and trust in superiors. This research also explores the antecedent and consequence of BPCC, namely budget participation requirements and product innovation performance, and probes the relationships among the three.

\subsection{Budgeting Participation Requirement (BPR) and Product Innovation Performance (PIP)}

Budgeting participation requirement is one of the most important problems in management accounting research. Previous budgeting studies have put a lot of attention on how a managers' reaction affects participation in the organization's budgeting process. Previous studies have also shown benefits to participating in many aspects, such as the sharing job-related information [31], decreasing information asymmetric [32], diminishing managers' role ambiguity [33], improving organizational affective commitment [34], trust 
in superiors [35], and reducing job-related tension [36,37]. However, previous empirical research provides the inconsistent results for budgeting participation in the impact of job satisfaction and performance. Some studies have shown a significant positive relation between budgeting participation and performance [21,22], while others show minimal positive $[23,24,38]$, or even negative [25] relationships. In the association between satisfaction and budget participation, some studies show a positive effect $[23,36,39]$, some studies are insignificant [40].

Previous budgeting studies employ contingency viewpoints [41,42] and mediating variables $[32,34,37,39]$ to explicate the inconsistency. However, managerial accounting researchers indicate budgetary participation requirement is a means for improving managerial outcomes. Hence, the relationships between budgeting participation and product innovation outcomes need further investigation through various theories and viewpoints. This study attempts to use the relationship between the social exchange theory and psychological contract theory and proposed that a budgeting participation requirement can provide opportunities for exchanges between superiors and subordinates. Not only to enhance the high management cognitive, but also improve the management attitude, and improve their affective commitment and product innovation outcomes. Therefore, this study develops the following hypothesis:

Hypothesis 1 (H1). Budgeting participation requirement is positively related to product innovation performance.

\section{2. $B P C C$}

The BPCC is a configuration that includes three organizational factors in this study: procedural justice, self-efficacy, and trust in superiors. This study suggests that these factors should exhibit a certain degree of alignment for coping with budgeting participation requirement and then improving product innovation performance. Each concept of these factors is explained below.

Procedural justice in organizational decision making has been examined in a number of contexts, including budgeting and related settings such as pay allocation and performance appraisal [43-45]. Procedural justice affects the fairness of distribution and is therefore the main component of organizational justice. In assessing procedural justice, employees require that formal organizational decision-making procedures should provide them an opportunity to voice their opinions and to appeal unfavorable decisions, and that such procedures should be applied consistently across persons and over time [46-48].

Self-efficacy is proposed by the famous psychologist Bandura [49]. Self-efficacy refers to the confidence that an individual has sufficient ability to complete a task. It has nothing to do with personal skills or abilities but is related to the self-judgment of personal abilities. The perception of self-efficacy determines the behavior of an individual in a specific situation, including the way of thinking and emotional response, which is the belief in the individual's own abilities [49]. People with a strong sense of self-efficacy can increase their sense of personal accomplishment and interest; they can transform difficult tasks into training without avoiding other threats. In the face of failure, they will review this because they did not work hard enough, or lacked enough knowledge or skills, which would force them to work harder [1]. Maintaining a high sense of self-efficacy can promote personal achievement energy, reduce stress, and avoid excessive depression [49].

Trust is seen as an individual's desire to rely on the beliefs of the other party with positive self-confidence expectations [50,51], which was introduced by Lewis and Weigert [52]. According to McAllister [53], impact-based trust is an individual's belief in the care and consideration of others and is considered to have a significant relationship with an individual's performance. In addition, affective events theory shows that the emotional attitude of an employee is a characteristic that affects the work environment. Therefore, this study specifies superior trust as impact-based trust. Participatory budgeting enhances managers' trust in superiors [35]. Participation in budgeting provides an opportunity for managers to express their views and perspectives in budget decision-making [35,39]. In addition, a pos- 
itive link between trust and performance is proposed and validated [53-55]. The company performance will benefit from trust because managers with a high degree of trust in their superiors believe that their participation will be treated fairly and reasonably. Therefore, this study suggests that a high level of trust in superiors will improve management skills.

\section{3. $B P R$ and $B P C C$}

The need for budgeting participation will affect the fairness of the organization's internal procedures, the manager's self-efficacy, and the trust in superiors that form the budgeting participation capability configuration (BPCC). Traditionally, it is believed that high $R \& D$ density mainly occurs in the electronics-related industry. However, when the company is facing ever-changing technology and customer needs, in order to produce unique products, a large amount of research and development funds are required. To obtain sufficient funds, it is more and more important for managers to participate in the budget [56]. In budget participation, managers consider the openness and fairness of decision-making, so the organization needs procedural justice. In addition to procedural fairness, the self-efficacy of managers is also needed to come up with an appropriate budget. Of course, a successful budget decision also depends on the manager's trust in their superiors. Through trust in superiors, the transfer and use of knowledge between departments and professionals will be smoother [57].

In summary, in order to respond to the requirement of budget participation, the internal resources of the enterprise will form a high degree of budgeting participation capabilities. This study believes that this ability is formed by procedural justice, manager's self-efficacy, and trust in superiors, and believes that the three factors are indispensable and should be closely combined to exert effective innovation ability. Therefore, this study argues that the need for budget participation will positively affect the degree of internal integration of the three factors. That is, the higher the demand for budget participation, the degree of internal integration among procedural justice, self-efficacy, and trust in superiors (the three factors form BPCC) will be higher. Therefore, we proposed the following two hypotheses.

Hypothesis 2 (H2). Procedural justice, self-efficacy, and trust in superiors are positively related to BPCC.

Hypothesis 3 (H3). Budgeting participation requirement is positively related to BPCC.

\subsection{BPCC and PIP}

As mentioned earlier, the requirement for budget participation is closely related to a firm's organizational procedural justice, manager's self-efficacy, and trust in superiors. In the relation between an external environment and an organizational strategy, since the customer's preference is changeable and the competitor's threat is indistinct, the environment confronted by managers is constantly variable and cannot be fully controlled. In this situation, for satisfying the customer's needs and manufacturing unique products, a firm should actively develop and innovate to create competitive advantages on important product attributes $[15,16,58-60]$. Namely, when facing a high perceived budget participation requirement to cope with changeable environment, a firm will adopt an innovation strategy.

Levitt [61] suggested that product innovation does not have to be pure or comprehensive innovation, even a kind of imitation and improvement is also innovation. From the consumer point of view, product innovation is based on whether new products add more benefits to consumers, but this benefit depends on the consumer's own perception. This study believes that for a company, whether it is improving existing products or releasing new products for the first time, as long as it can make innovative products reach the goal of higher than the average sales of the industry, it can be regarded as product innovation. In light of Porter's $[58,59]$ typology of strategy, the differentiation strategy pertains to pursuing product unique in customer's caring aspects such as product quality, brand image and customer services. To be unique, the firm commonly uses innovative approaches to design products and satisfy its customer. Todtling et al. [62] indicated that different types of innovations need different types of knowledge sources and linkages. This study built 
the construct for measuring product innovation, on the basis of the following criteria that are conceptualized and used in previous empirical studies regarding innovation, such as Avlonitis et al. [63], Bisbe and Otley [64], Deshpande et al. [65], and Subramanian and Nilakanta [66].

Furthermore, in order to perform the differentiation strategy successfully in budget participation requirement, an organizational BPCC will show a certain degree of procedural justice, self-efficacy, and trust in superiors. In such an aligned BPCC, due to the organizational procedural fairness, manager's self-efficacy, and trust in superiors being provided appropriately, an organization's budget resources will be executed effectively. That is, these organizational factors will fit mutually to cope with an external innovation requirement, and in turn help the achievement of organizational innovation goal as well as performance improvement. Inversely, when these factors can not fit each other to show an effective BPCC, these inconsistent factors will inhibit the achievement of the organizational goal and be detrimental to the organizational performance. In organization and accounting literature, prior studies also suggested that, given the environment, if organizational control elements can be coordinated as a solid configuration during organization's design or change, the organizational performance will be improved $[2,67]$. Therefore, this study suggests that when a firm's BPCC is designed to cope with the budget participation requirement, such a BPCC in terms of procedural justice, manager's self-efficacy, and trust in superiors will be positively related to product innovation performance. Namely, the higher the degree of internal alignment of BPCC in terms of procedural justice, self-efficacy, and trust in superior, the higher the product innovation performance will be. The following hypothesis thereby proposed:

Hypothesis 4 (H4). BPCC is positively related to product innovation performance.

\section{Research Method}

Figure 1 is the conceptual framework of this study, and the hypothesis symbols depict the relationships between research variables.

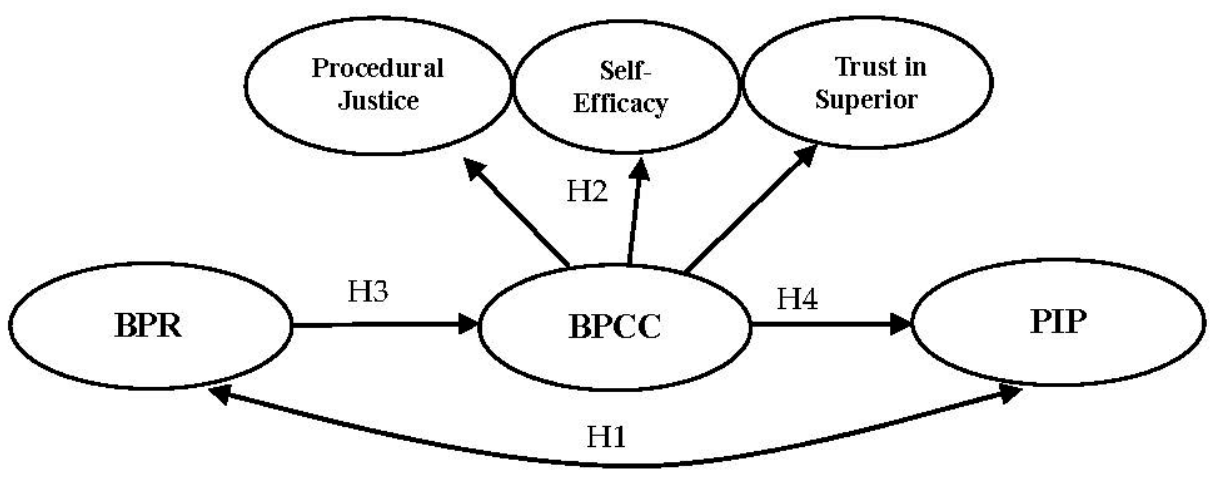

Figure 1. Research model. Note: BPR: budgeting participation requirement; BPCC: budget participation capacity configuration; PIP: product innovation performance.

\subsection{Sample and Data Collection}

The theme of this study is to explore the organizational factors that can produce product innovation capabilities and improve product innovation performance. Therefore, Taiwan's electronics-related industries that emphasize product innovation are the population of investigation, including semiconductors, optoelectronics, electronic components, computers, and peripherals. The subordinate managers of the production department of the industrial companies are the subjects of the survey. The subordinate managers refer to the managers who play a role in the budgeting process and must communicate with their superiors for their budget results. This study employed a cross-sectional questionnaire survey to randomly select companies in the above-mentioned industries from the Taiwan Stock 
Exchange. Since the survey subjects are from listed electronic or technology companies that meet the theme of innovation, the selected samples have representativeness. A mail questionnaire with a cover letter and a self-addressed prepaid envelope was forwarded. A total of 630 questionnaires were sent out and 187 responses were received. After deleting 5 incomplete questionnaires, the remaining 182 were valid, getting an effective recovery rate of $28 \%$. The age of the respondents was $36-45$ years old accounting for $41 \%$ and $46-55$ years old accounting for $27 \%$. The average length of work in their company was 5.2 years. $94 \%$ have a bachelor's degree or above.

\subsection{Measures}

The research instruments were primarily taken from previous studies. Moreover, empirical validity was further checked by confirmatory factor analysis (CFA), a powerful and indispensable method of construct validity [68]. The CFA analysis results show that the factor loading of all items of each variable is near or exceeds the level of 0.7 , and the composite reliability exceeds 0.7. In addition, the Cronbach's [69] alpha coefficients were calculated to assess the reliability of each variable. By these analyses, the measures were proven to have reasonable validity and reliability.

\subsubsection{Budgeting Participation Requirement}

This study used Milani's [23] six-item scale, which has frequently been employed in prior studies. The instrument includes several aspects of budgetary participation: frequency, involvement, influence, importance of subordinate input, and the supervisor's explanations for change. Items such as "The frequency of budget-related discussion with supervisor initiated by me" and "The amount of reasoning providing to me by a supervisor when the budget is revised" were included. The scale includes seven points ranging from 1 (strongly disagree) to 7 (strongly agree). Previous studies have reported satisfactory validity and reliability for the scale $[22,24,34,70]$. Higher score reflects higher perceived budgetary participation requirement.

\subsubsection{BPCC}

The BPCC was operationalized as the internal alignment among procedural justice, self-efficacy, and trust in superiors. The procedures justice was measured by a tool developed by McFarlin and Sweeney [71]. It includes four items and requires subordinates to rate the fairness of procedures used to convey performance feedback to superiors, determine salary increases, and evaluate performance and portability. Choice 1 means the lowest level of fairness, and choice 7 means the highest level.

The self-efficacy was operationalized as the extent to which managers feel confident about their job skills, abilities, qualifications, and confidence. The measure is an eight-item scale. Items such as "My job is well within the scope of my abilities" and "I feel that I am overqualified for the job I am doing" were included. Managers were asked to rate each item on a seven-point scale ranging from 1 (strongly disagree) to 7 (strongly agree). Higher score reflects higher perceived self-efficacy.

To measure trust in superiors in this study, McAllister's [53] five-item instrument was employed to measure emotional trust held by subordinates in their superiors. McAllister [53] provided evidence for the convergent and discriminate validity of this measure. Items such as "We have a sharing relationship. We can both freely share our ideas, feelings and hopes" and "I can talk freely to my superior about difficulties I am having at work and know that my superior will want to listen" were included. The seven-point Likert-type scale ranging from 1 (strongly disagree) to 7 (strongly agree) was used, and a higher score reflects higher trust in superiors.

\subsubsection{Product Innovation Performance}

This study uses the same product innovation performance measurement as Bisbe and Otley [64]. Product innovation performance is concerned with generating ideas or with 
the creation of something entirely new that is reflected in a change in the end product or service including the number of innovations, the speed of the innovation, the level of innovativeness, and being the 'first' in the market. The seven-point Likert-type scale ranges from 1 (strongly disagree) to 7 (strongly agree). The higher the score, the higher the product innovation performance.

\section{Results}

This study employed structural equation modeling (SEM) to test the hypotheses, and the results of the statistical analysis are presented in this section. Kline [72] suggested that SEM is the preferred method to analyze multiple relationships simultaneously and provides measures of overall model fit. In addition, SEM also provides the significance of each if there are relationships between variables and results in a better ability to model multiple relationships than path analysis and multiple regressions.

\subsection{Descriptive Statistics, Correlation and Reliability}

The descriptive statistics of each variable and correlation coefficients between variables are shown in Table 1. Reliabilities of variables were also calculated and shown in Table 1. Cronbach's [69] alpha coefficients were judged acceptable using Nunnally's [73] criteria of a minimum value of 0.7 . It can be seen from the table, budgeting participation requirement has significant relationship with procedural justice, trust in superiors, self-efficacy, and product innovation performance. Additionally, procedural justice has significant relationship with trust in superiors and self-efficacy. Since the Cronbach's $\alpha$ value of all variables exceeds 0.7 , each variable has good internal consistency.

Table 1. Means, Standard Deviations, Correlations, and Cronbach's $\alpha$ for Variables.

\begin{tabular}{|c|c|c|c|c|c|c|}
\hline Measure & Mean (SD) & BPR & PJ & Trust & SE & Cronbach's $\alpha$ \\
\hline BPR & $\begin{array}{c}5.469 \\
(1.236)\end{array}$ & - & & & & 0.851 \\
\hline PJ & $\begin{array}{c}5.881 \\
(2.862)\end{array}$ & $0.296^{* *}$ & & & & 0.827 \\
\hline Trust & $\begin{array}{c}5.013 \\
(3.954)\end{array}$ & $0.302 * *$ & 0.134 * & & & 0.786 \\
\hline SE & $\begin{array}{c}6.320 \\
(2.627)\end{array}$ & $0.418^{* * *}$ & $0.409^{* * *}$ & 0.102 & & 0.826 \\
\hline PIP & $\begin{array}{c}6.124 \\
(2.595)\end{array}$ & 0.152 * & 0.091 & 0.063 & 0.029 & 0.794 \\
\hline
\end{tabular}

Note: BPR: budgeting participation requirement, PJ: procedural justice, Trust: trust in superiors, SE: self-efficacy, PIP: product innovation performance; ${ }^{*} p<0.05,{ }^{* *} p<0.01,{ }^{* * *} p<0.001$.

\subsection{Structure Model Analysis and Hypothesis Testing}

LISREL 8.52 was used to analyze the structure model of this study. We included a range of fit indices to measure the full model, such as Chi-square, Goodness-of Fit (GFI), Adjusted Goodness-of Fit (AGFI), Akaike Information Criterion (AIC), and Comparative Fit Index (CFI). A good fit model should have a non-significant Chi-square and a minimum of 0.90 for the GFI index. AGFI and AIC were used to measure model parsimony. It has been suggested that GFI and AGFI have a good fit minimum cutoff of 0.9, CFI is above 0.95 [74], and that the AIC should be less than that of the saturated model. In addition, the root-mean-square error of approximation (RMSEA) indicator is used to test the suitability of the overall model, and the value is preferably less than 0.08 [75]. The statistical analysis results are presented in Table 2. The results indicated acceptable model fit for a number of fit indices, such as the Chi-square is not significant ( $\mathrm{df}=226, p=0.351)$, and all other fit indices can be seen to be above acceptable levels (GFI $=0.937$; AGFI $=0.921$; CFI $=1.000$; AIC $=26.241$ (saturated model 30), RMSEA $=0.05$ ). A summary of the coefficients for each path is also shown in Figure 2. Since the path coefficient between BPR and PIP is positive but not significant $(0.193, p>0.05), \mathrm{H} 1$ that there is a significant relationship between budgeting participation requirement and product innovation performance is 
not supported. As the paths from BPCC to PJ, SE, and Trust are all significant, showing that BPCC has significant relationships with procedural justice, self-efficacy, and trust in superior, respectively, $(0.519, p<0.001 ; 0.373, p<0.01 ; 0.417, p<0.01), \mathrm{H} 2$ is thus supported. In addition, the path from BPR to BPCC is significant $(0.551, p<0.001)$, and the path from BPCC to PIP is also significant $(0.323, p<0.01)$, so H3 and $\mathrm{H} 4$ are both supported. The final model indicated BPCC fully mediate the relationships between BPR and PIP.

Table 2. Hypothesized and Final Model: Structural Parameter Estimates.

\begin{tabular}{cccc}
\hline Hypothesis & Path & Coeff. & t-Value \\
\hline H1 & BPR $\rightarrow$ PIP & 0.193 & 0.712 \\
\hline & BPCC $\rightarrow$ PJ & 0.519 & $3.785^{* * *}$ \\
H2 & BPCC $\rightarrow$ SE & 0.373 & $2.820^{* *}$ \\
& BPCC $\rightarrow$ Trust & 0.417 & $3.027^{* *}$ \\
\hline H3 & BPR $\rightarrow$ BPCC & 0.551 & $4.016^{* * *}$ \\
\hline H4 & BPCC $\rightarrow$ PIP & 0.323 & $2.613^{* *}$
\end{tabular}

Chi-square $=240.022(\mathrm{df}=226, p=0.351), \mathrm{GFI}=0.94, \mathrm{AGFI}=0.927, \mathrm{CFI}=1.000, \mathrm{AIC}=27.182($ saturated model 30) RMSEA $=0.05$, Note: BPR: budgeting participation requirement, PIP: product innovation performance, BPCC: budget participation capacity configuration, PJ: procedural justice, SE: self-efficacy, Trust: trust in superiors; ${ }^{* * *} p<0.001,{ }^{* *} p<0.01$.

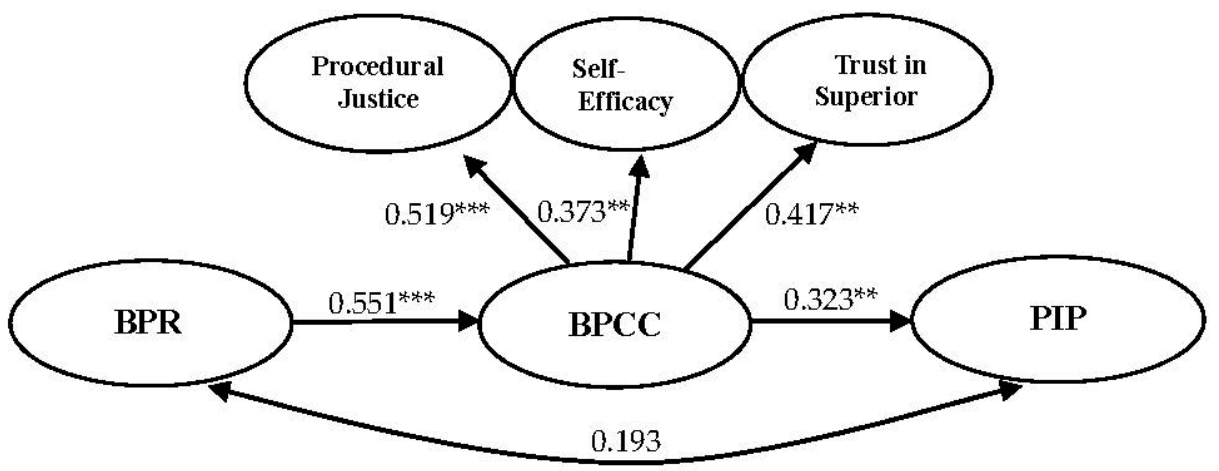

Figure 2. Structural model and final results. Note: BPR: budgeting participation requirement, BPCC: budget participation capacity configuration, PIP: product innovation performance; ${ }^{* * *} p<0.001$, ** $p<0.01$.

\section{Discussion}

From the results of this study, we found that BPCC plays a fully mediating role between BPR and product innovation outcomes. This completely mediated result once again explains the weak relationship between budget participation requirement and organizational performance in previous studies $[23,24,38]$. Furthermore, the results of this study confirm that budget participation is related to procedural justice, self-efficacy, and trust in superiors, which are consistent with the results of previous related studies $[1,18,19,75]$. This study further confirms that procedural justice, self-efficacy, and trust in superiors integrate into a budget participation capacity configuration. Thus, this study is different from the previous discussion of the individual relationship between budget participation and the three variables, but further explores the relationship between budgeting participation and the integration of these variables. This research also confirms that a module composed of procedural justice, self-efficacy, and trust in superiors can improve product innovation performance, so this module essentially forms a product innovation capability. The results are consistent with the views that the interdependence of management control elements can bring product innovation capability [15], and the product innovation capabilities can improve organizational performance [16,67]. 


\section{Conclusions}

This study aims to explore how to improve product innovation capability and innovation performance. The three organizational behavior elements from budget participation, including procedural justice, self-efficacy, and trust in superiors, form a structure of innovation capability, which we call Budget Participation Capacity Configuration (BPCC). Additionally, exploring the relationships between BPCC and its antecedent variablebudgeting participation requirement and consequence variable-product innovation performance. This study used Taiwan-listed electronics-related companies as the research population, and the research subject is the company's production manager. We adopted questionnaire survey method to collect data, and structural equation model to verify the research hypothesis. The research results show that the three organizational factors of procedural justice, self-efficacy, and trust in superiors can indeed be integrated to form a BPCC, producing product innovation capabilities. Therefore, issue one of this study has been answered in the affirmative. In addition, the study found that budget participation requirement significantly positively affects BPCC, and BPCC also positively affects product innovation performance. Therefore, issue two of this research has also been answered in the affirmative.

\subsection{Management Implications and Contributions}

The results of this study have enlightening management implication for the management of companies. When the management thinks about product innovation capabilities, they should strategically encourage managers to participate in budget decisions. This participation can increase the self-efficacy of managers, increase trust in superiors, and strengthen procedural justice; the joint improvement of these aspects will generate innovation capability and become a source of product innovation capability. Regarding the academic contribution of this study, firstly, this research adopts the viewpoint that organizational control elements should be integrated to form an innovation capability. The organizational behavior variables related to budget participation, including procedural justice, self-efficacy, and trust in superiors, are grouped to form a configuration generating product innovation capabilities. The result confirms the viewpoint that the integration of organizational elements produces innovation capabilities. This study adopts the view of integrating variables, which is different from previous studies that only explored individual variables. Second, the results of this study provide an explanation for the inconsistent conclusions of previous studies on the relationship between budget participation and organizational effectiveness. This study argues that there is an intermediary variable between the two causal variables, such as the BPCC in this study, which plays a pivotal role in making the two variables closely related. The contribution of this research to the practice is to suggest that the management of company should attach importance to managers' budget participation, because it can strengthen procedural justice, increase managers' self-efficacy, and trust in their superiors. The enhancement of these functions is helpful to promote innovation capabilities and bring about product innovation performance.

\subsection{Limitation and Future Research Recommendation}

This research method adopts the questioning survey. The survey population is companies of Taiwan-listed electronics-related industries. Since the sample comes from a single region and limited industries, as well as the questionnaire response rate of these industries is generally low, the number of samples that can be used for analysis is not high in this study. In order to increase the number of samples, it is recommended that future research can include other industries, so that the research conclusions can be more robust and generalized. In terms of research method, it is suggested that future research can adopt qualitative analysis and time series approach, so that the causality of research variables can be more certain, and the research conclusions are more complete. 
Author Contributions: Conceptualization, S.-H.C.; Formal analysis, K.-C.C.; Investigation, H.-M.W. and K.-H.W.; Project administration, M.-J.H. All authors have read and agreed to the published version of the manuscript.

Funding: This research received no external funding.

Institutional Review Board Statement: Ethical review and approval were waived for this study, due to this research adopting the questionnaire survey and the research subjects being randomly sampled from electronic-related industrial managers and the answers being anonymous.

Informed Consent Statement: Informed consent was obtained from all subjects involved in the study.

Data Availability Statement: The research data can be requested by the authors' consent.

Conflicts of Interest: The authors declare no conflict of interest.

\section{References}

1. Ni, F.Y.; Su, C.C.; Chung, S.H.; Cheng, K.C. Budgetary participation's effect on managerial outcomes: Mediating roles of self-efficacy and attitudes toward budgetary decision makers. NTU Manag. Rev. 2009, 19, 321-348. [CrossRef]

2. Cheng, K.C.; Yang, M.L.; Su, C.C.; Ting, N.J. How can budget control and management accounting system improve product innovation performance? Sun Yat-Sen Manag. Rev. 2013, 21, 545-577.

3. Cheng, K.C.; Cheng, C.T.; Shih, N.S. The influence of budgetary participation by R\&D managers on product innovation performances: The effect of trust, job satisfaction and information asymmetry. Asia Pac. Manag. Rev. 2014, 19, $133-150$.

4. Su, M.F.; Cheng, K.C.; Chung, S.H.; Chen, D.F. Innovation capability configuration and its influence on the relationship between perceived innovation requirement and organizational performance: Evidence from IT manufacturing companies. J. Manuf. Technol. Manag. 2018, 29, 1316-1331. [CrossRef]

5. Mascitelli, R. From experience, harnessing tacit knowledge to achieve breakthrough innovation. J. Prod. Innov. Manag. 2000, 17, 179-193. [CrossRef]

6. $\quad$ Olson, E.M.; Walker, O.C., Jr.; Ruekerf, R.W.; Bonnerd, J.M. Patterns of cooperation during new product development among marketing, operations and R\&D: Implications for project performance. J. Prod. Innov. Manag. 2001, 18, $258-271$.

7. Parthasarthy, R.; Hammond, J. Product innovation input and outcome: Moderating effects of the innovation process. J. Eng. Technol. Manag. 2002, 19, 75-91. [CrossRef]

8. Ramesh, B.; Tiwana, A. Supporting collaborative process knowledge management in new product development teams. Decis. Support Syst. 1999, 27, 213-235. [CrossRef]

9. Romijn, H.; Albaladejo, M. Determinants of innovation capability in small electronics and software firms in Southeast England. Res. Policy 2002, 31, 1053-1067. [CrossRef]

10. Yam, R.C.; Guan, J.C.; Pun, K.F.; Tang, E.P. An audit of technological innovation capabilities in Chinese firms: Some empirical findings in Beijing, China. Res. Policy 2004, 33, 1123-1140. [CrossRef]

11. Pinto, M.B.; Pinto, J.; Prescott, J. Antecedents and consequences of project team cross-functional cooperation. Manag. Sci. 1993, 39, 1281-1297. [CrossRef]

12. Sher, P.J.; Lee, V.C. Information technology as a facilitator for enhancing dynamic capabilities through knowledge management. Inform. Manag. 2004, 41, 933-945. [CrossRef]

13. Wang, T.Y.; Hu, J.M. Heuristic method on solving an inventory model for products with optional components under stochastic payment and budget constraints. Expert. Syst. Appl. 2010, 37, 2588-2598. [CrossRef]

14. Wang, X.; Dass, M. Building innovation capability: The role of top management innovativeness and relative-exploration orientation. J. Bus. Res. 2017, 76, 127-135. [CrossRef]

15. Henri, J.F.; Wouters, M. Interdependence of management control practices for product innovation: The influence of environmental unpredictability. Account. Org. Soc. 2020, 86, 101073. [CrossRef]

16. Li, G.H. A review of the literature of the relationship between innovation and internationalization of SMEs and future prospects. Am. J. Ind. Bus. Manag. 2020, 10, 619-636. [CrossRef]

17. Libby, T. The influence of voice and explanation on performance in a participative budgeting setting. Account. Org. Soc. 1999, 24, 125-137. [CrossRef]

18. Libby, T. Referent cognitions and budgetary fairness: A research note. J. Manag. Account. Res. 2001, 13, 91-105. [CrossRef]

19. Abernethy, M.A.; Bouwens, P.; Kroos, J.P. Organization identity and earnings manipulation. Account. Org. Soc. 2017, 58, 1-14. [CrossRef]

20. McDonald, R.P.; Ho, M.H.R. Principles and practice in reporting structural equation analyses. Psychol. Meth. 2002, 7, 64-82. [CrossRef]

21. Merchant, K.A. The design of corporate budgeting systems: Influence on managerial behavior and performance. Account. Rev. 1981, 4, 813-829.

22. Brownell, P. The role of accounting data in performance evaluation, budgetary participation, and organizational effectiveness. J. Account. Res. 1982, 20, 12-27. [CrossRef] 
23. Milani, K. The relationship of participation in budget-setting to industrial supervisor performance and attitudes: A field study. Account. Rev. 1975, 50, 274-284.

24. Dunk, A.S. Budget emphasis, budgetary participation and managerial performance: A note. Account. Org. Soc. 1989, 14, 321-324. [CrossRef]

25. Cherrington, D.; Cherrington, J. Appropriate reinforcement contingencies in budgeting process. J. Account. Res. 1973, 11, 225-253. [CrossRef]

26. Venkatraman, N. The concept of fit in strategy research: Toward verbal and statistical significant. Acad. Manag. Rev. 1989, 14, 423-444. [CrossRef]

27. Baines, A.; Langfield-Smith, K. Antecedents to management accounting change: A structural equation approach. Account. Org. Soc. 2003, 28, 675-698. [CrossRef]

28. Chenhall, R.H. Management control systems design within its organizational context: Findings from contingency-based research and directions for the future. Account. Org. Soc. 2003, 28, 127-168. [CrossRef]

29. Meyer, A.D.; Tsui, A.S.; Hinings, C.R. Configurational approaches to organizational analysis. Acad. Manag. J. 1993, 36, 1175-1195.

30. Miller, D. Strategy making and structure: Analysis and implications for performance. Acad. Manag. J. 1987, 31, 7-32.

31. Parker, R.J.; Larissa, K. Erratum to "vertical information sharing in the budgeting process". Account. Org. Soc. 2007, 32, 495-496. [CrossRef]

32. Kren, L. Budgetary participation and managerial performance: The impact of information and environmental volatility. Account Rev. 1992, 67, 511-526.

33. Chenhall, R.H.; Brownell, P. The effect of participative budgeting on job satisfaction and performance: Role ambiguity as an intervening variable. Account. Org. Soc. 1986, 13, 225-233. [CrossRef]

34. Nouri, H.; Parker, R.J. The relationship between budget participation and job performance: The roles of budget adequacy and organizational commitment. Account. Org. Soc. 1998, 23, 467-483. [CrossRef]

35. Magner, N.; Welker, R.B.; Campbell, T.L. The interactive effect of budgetary participation and budget favorability on attitudes toward budgetary decision makers: A research note. Account. Org. Soc. 1995, 20, 611-618. [CrossRef]

36. Kennis, I. Effects of budgetary goal characteristics on managerial attitudes and performance. Account. Rev. 1979, 54, 707-721.

37. Shields, J.M.; Pruitt, K.; McFall, A.; Shaub, A.; Der, C.J. Understanding ras: 'it ain't over 2019til it's over'. Trends Cell Biol. 2000, 10, 147-154. [CrossRef]

38. Brownell, P.; Hirst, M. Reliance on accounting information, budgetary participation, and task uncertainty: Tests of a three-way interaction. J. Account. Res. 1986, 24, 241-249. [CrossRef]

39. Chenhall, R.H.; Morris, D. The impact of structure, environment, and interdependence on the perceived usefulness of management accounting systems. Account. Rev. 1986, 61, 16-35.

40. Brownell, A.J. Counseling men through bodywork. Pers. Guid. J. 1991, 60, 252-255. [CrossRef]

41. Brownell, P. Leadership style, budgetary participation and managerial behavior. Account. Org. Soc. 1983, 8, 307-321. [CrossRef]

42. Brownell, P. A model for listening instruction: Management applications. Bull. Assoc. Bus. Commun. 1985, 48, 39-44. [CrossRef]

43. Brockner, J.; Wiesenfeld, B.M. An integrative framework for explaining reactions to decisions: Interactive effects of outcomes and procedures. Psychol. Bull. 1996, 120, 189-208. [CrossRef]

44. Colquitt, J.A. On the dimensionality of organizational justice: A construct validation of a measure. J. Appl. Psychol. 2001, 86, 386-400. [CrossRef]

45. Greenberg, J. Employee theft as a reaction to underpayment inequity: The hidden cost of pay cuts. J. Appl. Psychol. 1990, 75, 561-568. [CrossRef]

46. Leventhal, G.S. What should be done with equity theory? New approaches to the study of fairness in social relationships. In Social Exchange: Advances in Theory and Research; Gergen, K.J., Greenberg, M.S., Willis, R.H., Eds.; Springer: Boston, MA, USA, 1980; pp. 27-55.

47. Greenberg, J. Determinants of perceived fairness of performance evaluations. J. Appl. Psychocol. 1986, 71, 340-342. [CrossRef]

48. Barrett-Howard, E.; Tyler, T.R. Procedural justice as a criterion in allocation decisions. J. Pers. Soc. Psychol. 1986, 50, 296-304. [CrossRef]

49. Bandura, A. Fearful expectations and avoidant actions as coeffects of perceived self-inefficacy. Am. Psychol. 1986, 41, 1389-1391. [CrossRef]

50. Das, T.K.; Teng, B.S. Between trust and control: Developing confidence in partner cooperation in alliances. Acad. Manag. Rev. 1998, 23, 491-512. [CrossRef]

51. Lewicki, R.; McAllister, D.; Bies, R. Trust and distrust: New relationships and realities. Acad. Manag. Rev. 1998, 23, 438-458. [CrossRef]

52. Lewis, D.J.; Weigert, A. Trust as a social reality. Soc. Forces 1985, 63, 967-985. [CrossRef]

53. McAllister, D.J. Affect- and cognition-based trust as foundations for interpersonal cooperation in organizations. Acad. Manag. J. 1995, 38, 24-59.

54. Earley, P.C. Trust, perceived importance of praise and criticism, and work performance: An examination of feedback in the United States and England. J. Manag. 1986, 12, 457-473. [CrossRef]

55. Dirks, K.T.; Ferrin, D. The role of interpersonal trust in organizational settings. Org. Sci. 2001, 12, 450-467. [CrossRef] 
56. Bouwens, J.; Abernethy, M.A. The consequences of customization on management accounting system design. Account. Org. Soc. 2000, 25, 221-241. [CrossRef]

57. Cooper, C.L. The development of a framework for a comprehensive approach to stress management interventions at work. Int. J. Stress Manag. 2003, 10, 280-296.

58. Porter, M.E. Competitive Strategy; Free Press: New York, NY, USA, 1980.

59. Porter, M.E. The competitive advantage of notions. Harvard Bus. Rev. 1990, 68, 73-93.

60. Miller, D. Relating Porter's business strategies to environment and structure: Analysis and performance implications. Acad. Manag. J. 1988, 31, 280-308.

61. Levitt, T. Innovative imitation. Harvard Bus. Rev. 1966, 44, 63-70.

62. Todtling, F.; Lehner, P.; Kaufmann, A. Do different types of innovation rely on specific kinds of knowledge interactions? Technovation 2009, 29, 59-71. [CrossRef]

63. Avlonitis, G.J.; Kouremenos, A.; Tzokas, N. Assessing the innovativeness of organizations and its antecedents: Project innovstrat. Eur. J. Mark. 1994, 28, 5-28. [CrossRef]

64. Bisbe, J.; Otley, D.T. The effects of the interactive use of management control systems on product innovation. Account. Org. Soc. 2004, 29, 709-737. [CrossRef]

65. Deshpande, R.; Farley, J.U.; Webster, F.E. Corporate culture customer orientation and innovativeness in Japanese firms: A quadrad analysis. J. Mark. 1993, 57, 23-27. [CrossRef]

66. Subramanian, A.; Nilakanta, S. Organizational innovativeness: Exploring the relationship between organizational determinants of innovation, types of innovations, and measures of organizational performance. Omega 1996, 24, 631-647. [CrossRef]

67. Falahat, M.; Ramayah, T.; Soto-Acosta, P.; Lee, Y.Y. SMEs internationalization: The role of product innovation, market intelligence, pricing and marketing communication capabilities as drivers of SMEs' international performance. Technol. Forecast. Soc. 2020, 152, 119908. [CrossRef]

68. Kerlinger, F.N.; Lee, H.B. Foundation of Behavior Research; Thomson Learning: Wadsworth, OH, USA, 2000.

69. Cronbach, L.T. Coefficient alpha and the internal structure of tests. Psychometrika 1951, 16, 297-334. [CrossRef]

70. Mia, L. Managerial attitude, motivation and the effectiveness of budget participation. Account. Org. Soc. 1988, 13, 465-475. [CrossRef]

71. McFarlin, D.B.; Sweeney, P.D. Distributive and procedural justice as predictors of satisfaction with personal and organizational outcomes. Acad. Manag. J. 1992, 35, 626-637.

72. Kline, R.B. Principles and Practice of Structural Equation Modeling, Methodology in the Social Sciences; Guilford Press: New York, NY, USA, 1998.

73. Nunnally, J.C. Vanishing individual differences just stick your head in the sand and they will go away. J. Instruct. Psychol. 1976, 3, 28-40.

74. Bentler, P.M. Comparative fit indexes in structural models, comparative fit indexes in structural models. Psychol. Bull. 1990, 107, 238-246. [CrossRef]

75. McDonald, T.; Siegall, M. The effects of technological self-efficacy and job focus on job performance, attitudes, and withdrawal behaviors. J. Psychol. 1992, 126, 465-475. [CrossRef] 